\title{
Analisis Kesulitan Siswa SMP dalam Menyelesaikan Soal Materi Operasi Hitung Pecahan Campuran Ditinjau dari Kemampuan Berpikir Reflektif Matematis
}

\author{
Riski Arta Ananda ${ }^{1 *}$, Febrian $^{2}$, Linda Rosmery Tambunan ${ }^{3}$ \\ 1,2,3 Universitas Maritim Raja Ali Haji, Kota Tanjungpinang, 29111, Indonesia
}

Pengiriman: 25/Januari/2020; Diterima: 24/September/2021; Publikasi: 30/September/2021

DOI: https://doi.org/10.31629/jg.v6i2.1931

\begin{abstract}
Abstrak
Penelitian ini dilatarbelakangi hasil pengamatan dimana masih banyak siswa yang menganggap matematika merupakan mata pelajaran yang tergolong sulit sehingga siswa tidak dapat menerima pembelajaran dengan baik. Hal ini menyebabkan siswa mengalami kesulitan terutama dalam menyelesaikan persoalan matematika, terutama soal dalam bentuk cerita. Dalam menyelesaikan soal cerita siswa dibutuhan kemampuan berpikir reflektif matematis. Tujuan penelitian ini adalah mendeskripsikan hasil analisis kesulitan yang dialami siswa kelas VII SMP dalam menyelesaikan soal operasi hitung bilangan pecahan campuran ditinjau dari kemampuan berpikir reflektif matematis. Metode yang digunakan dalam penelitian ini adalah metode deskriptif. Subjek penelitian ini adalah siswa kelas VII SMP Negeri 14 Satu Atap Tanjungpinang tahun pelajaran 2018/2019. Penelitian ini menggunakan tes dan wawancara sebagai teknik pengumpulan data. Data yang telah diperoleh dianalisis menggunakan teknik analisis data kualitatif. Hasil penelitian ini adalah: 1) siswa kemampuan berpikir reflektif matematis tinggi tidak mengalami kesulitan; 2) siswa kemampuan berpikir reflektif sedang mengalami kesulitan menghubungkan konsep dan menerapkan prinsip untuk membuktikan kebenaran solusi; 3) siswa kemampuan reflektif matematis rendah mengalami kesulitan mengingat dan menerapkan konsep, kesulitan memahami maksud soal serta kesulitan menyelesaikan masalah nyata.
\end{abstract}

Kata kunci: kesulitan; operasi hitung bilangan; pecahan campuran; berpikir reflektif

\begin{abstract}
This research was based on observations of researchers, that there are still many students who think mathematics is a difficult lesson so students cannot receive learning well. This causes students difficulties in solving math problems, especially the problem in the form of stories. In solving students' story problems, they need mathematical reflective thinking skills. The purpose of this study was to describe the results of the analysis of the difficulties experienced by seventh grade students of junior high school in solving operational problems calculating mixed fractions in terms of mathematical reflective thinking skills. The method used in this research is descriptive method. The subjects were students of class VII SMP N 14 One Roof Tanjungpinang 2018/2019 school year. Data collection techniques using tests and interviews. The data that has been obtained is analyzed using qualitative data analysis techniques. The results of this study are: 1) students with high mathematical reflective thinking skills have no difficulties; 2) students' reflective thinking skills are having difficulty connecting concepts and applying principles to prove the truth of solutions; 3 ) students with low mathematical reflective abilities have difficulty remembering and applying concepts, difficulty understanding the meaning of the problem and difficulty solving real problems.
\end{abstract}

Keywords: difficulty; number counting operation; mixed fragments; reflective thinking

*Penulis Korespondensi

Email Address: riskiarta97@gmail.com

Handphone : : +62 85765438356 


\section{JURNAL GANTANG. September 2021; VI(2): 163 - 168 \\ p-ISSN. 2503-0671 \\ e-ISSN. 2548-5547}

\section{Pendahuluan}

Matematika merupakan ilmu penting yang akan dijumpai pada setiap sudut kehidupan. Banyak dari orang yang tidak menyadari bahwa dalam setiap kegiatanya terdapat ilmu matematika didalamnya. Ilmu matematika dapat digunakan untuk menyelesaikan permasalahan nyata yang ada dilingkungan sekitar. Seperti yang diungkapkan oleh Sholekah et al. (2018) matematika diperlukan oleh siswa untuk memenuhi kebutuhan guna memecahkan masalah dalam kehidupan sehari-hari, misalnya dapat mengoperasikan perhitungan seperti penjumlahan, pengurangan, perkalian dan pembagian, serta dapat mengaplikasikan konsep, dan lain sebagainya. Mengingat pentingnya ilmu matematika bagi kehidupan maka matematika dijumpai pada setiap jenjang pendidikan, mulai dari sekolah dasar hingga perguruan tinggi (Jarnal, 2014).

Pembelajaran matematika membutuhkan ketelitian baik dalam memahami konsep sampai menerapkan konsep yang dipelajari untuk menyelesaikan masalah yang dihadapi. Matematika merupakan ilmu yang didalamnya banyak terdapat banyak simbol, angka dan rumus. Karena alasan itu, matematika merupakan ilmu yang dianggap menakutkan oleh siswa. Sebagaimana yang dungkapkan Sholekah et al. (2018) matematika memerlukan ketekunan dan keuletan, sehingga matematika dianggap sebagai mata pelajaran yang membosankan dan rumit, bahkan menakutkan. Hal ini menyebabkan siswa sulit untuk menerima pembalajaran matematika oleh guru.

Kesulitan menurut Cooney dalam Abdurrahman (2003) dikategorikan dalam 3 jenis, yaitu: (a) kesulitan dalam mengingat konsep, dimana siswa sulit mengingat konsep dalam menyelesaikan soal, (b) kesulitan dalam menerapkan prinsip, dimana siswa sulit menerapkan prinsip yang telah dipelajari dalam menyelesaikan soal, (c) kesulitan dalam menyelesaikan maslaah verbal, dimana siswa suit menyelesaikan soal-soal berbentuk cerita. Menurut Fauzi (2018) menyatakan bahwa letak kesulitan siswa dalam menyelesaikan soal adalah (1) siswa menganggap dirinya sendiri tidak mampu untuk menyelesaikan soal tersebut atau kurangnya kepercayaan diri terhadap kemampuan yang dimiikinya, dan (2) siswa mengalami kesulitan dalam menafsirkan soal yang diakibatan oleh kurangnya kemampuan awal serta kemampuan verbal siswa dalam menerjemahkan soal kedalam bentuk matematis.

Kesulitan belajar yang dialami siswa akan menyebabkan hasil belajar yang didapatkan kurang baik. Jarnal (2014) mengatakan bahwa kesulitan belaja yang dialami siswa dapat disebabkan oleh faktor internal dan eksternal. Sebenarnya, matematika bukanlah ilmu yang sulit hanya saja matematika adalah ilmu yang membutuhkan ketelitian, kehati - hatian, keuletan dan ketekunan dalam menyelesaikan permasalahannya. Matematika menjadi sulit bagi siswa karena mereka telah menanamkan dalam kepala bahwa kata matematika akan selalu identik dengan kata sulit, sehingga setiap mendengar kata matematika siswa langsung memikirkan kata sulit. Hal ini ditegaskan oleh Sholekah et al. (2018) asumsi yang mengatakan matematika adalah mata pelajaran yang sulit terus berlangsung pada setiap jenjang pendidikan, menyebabkan matematika menjadi bayak tidak disukai, bahkan diabaikan, yang menyebabkan siswa mengalami kesulitan belajar.

Salah satu materi dalam matematika adalah materi pecahan. Materi pecahan merupakan salah satu materi berlanjut. Pada pembelajaran awal sekolah menengah pertama ditemui materi pecahan, kemudian dilanjutkan lagi pada materi pecahan bentuk aljabar. Sehingga materi dasar pecahan penting untuk dipelajari dan dikuasai siswa agar siswa mampu mengikuti pembelajaran pecahan selanjutnya. Materi pecahan juga erat kaitannya dalam kehidupan sehari-hari, karena tidak semua hal dapat dihitung hanya dengan menggunakan bilagan bulat. Untuk menyelesaikan masalah terkait materi pecahan dibutuhkan kemampuan berpikir reflektif matematis.

Kemampuan berpikir reflektif dapat 
digambarkan dengan kemampuan berpikir dimana siswa mampu mengidentifikasi informasi pada soal, menghubungkan dan mengolah pengetahuan yang dimilikiya guna menemukan solusi permasalahan, mengidentifikasi kesalahan dan memperbaikinya dan memberikan kesimpulan atas solusi permasalahan yang diperolehnya.

Penelitian ini mengadaptasi tingkatan berpikir reflektif menurut oleh Surbeck, Han dan Moyer (Prasetyowati et al., 2017) yang membagi berpikir reflektif menjadi 3 fase yaitu:

1. Reacting (berpikir reflektif untuk aksi), dalam fase ini hal - hal yang harus dilakukan peserta didik adalah:

a. Menyebutkan apa yang diketahui.

b. Menyebutkan apa saja yang ditanyakan.

c. Menyebutkan hubungan antara yang ditanya dan diketahui.

d. Mampu menjelaskan apa yang diketahui sudah cukup untuk menjawab apa yang ditanyakan.

2. Comparing (berpikir reflektif untuk evaluasi), pada fase ini peserta didik melakukan hal - hal sebagai berikut:

a. Menjelaskan jawaban pada permasalahan yang didapatkan.

b. Mengaitkan masalah yang ditanyakan dengan masalah serupa yang pernah ditanyakan sebelumnya.

3. Contemplating (berpikir reflektif untuk inkuiri kritis), pada fase ini peserta didik melakukan hal - hal sebagai berikut:

a. Menentukan maksud dari permasalahan.

b. Mendeteksi kebenaran dalam menentukan jawaban.

c. Mendeteksi jika terjadi kesalahan dalam menentukan jawaban yang tepat.

d. Memperbaiki dan menjelaskan jika terdapat kesalahan dalam menjawab.

e. Membuat kesimpulan dengan benar.

Berdasarkan latar belakang yang telah dipaparkan diatas maka, permasalahan yang akan diteliti dalam penelitian ini adalah: (1) Apa saja jenis kesulitan siswa kelas VII SMP dalam menyelesaikan soal pada materi opera hitung pecahan campuran ditinjau dari kemampuan berpikir reflektif matematis siswa?; (2) Apa faktor penyebab kesulitan itu terjadi. Sehingga tujuan dari penelitian ini adalah mendeskripsikan hasil analisil jenis kesulitan siswa menyelesaiakan soal materi operasi pecahan campuran dan faktor penyebabnya yang ditinjau dari kemapuan berpikir reflektif matemtis.

\section{Metode Penelitian}

Penelitian ini merupakan penelitian kualitatif deskriptif, kerena sesuai dengan tujuan dari penelitian ini yaitu mendeskripsikan hasil analisis kesulitan siswa kelas VII SMP dalam menyelesaikan soal materi operasi hitung pecahan campuran ditinjau dari kemampuan berpikir reflektif matematis.

Penelitian ini dilaksanakan pada salah satu Sekolah Menengah Pertama yang ada di Tanjungpinang, yaitu SMP N 14 Satu Atap pada bulan April 2019. Subjek penelitian adalah siswa kelas VII SMP N 14 Satu Atap Tanjungpinang tahun pelajaran 2018/2019. Pemilihan subjek penelitain ini didasarkan dari pengamatan yang dilakukan peneliti, yang mana siswa tidak mampu menyelesaikan soal terkait operasi hitung pecahan campuran.

Teknik pengumpulan data dalam penelitian ini menggunakan teknik tes dan wawancara. Soal tes terdiri dari 4 soal uraian menggunakan materi operasi hitung pecahan campuran untuk mengetahui kemampuan berpikir reflektif matematis siswa. Setiap soal memungkinkan siswa untuk menunjukan indikator berpikir reflektif, yaitu reacting (mengidentifikasi informasi pada soal), comparing (menggunakan pengetahuan untuk menemukan solusi penyelesaian soal) dan contemplating (mengidentifikasi kesalahan dan memperbaikinya, serta membuktikan kebenaran solusi).

Teknik wawancara digunakan sebagai penguat dari hasil tes. Wawancara yang digunakan adalah wawancara semi terstruktur. untuk mendapatkan hasil yang tidak didapatkan dari hasil tes. Wawancara dapat juga digunakan 


\section{JURNAL GANTANG. September 2021; VI(2): 163 - 168 \\ p-ISSN. 2503-0671 \\ e-ISSN. 2548-5547}

untuk mengetahui faktor yang menyebabkan siswa kesulitan menyelesaikan soal yag diberikan.

Teknik analisis data yang digunakan dalam penelitian ini adalah teknik analisis data kualitatif model Miles dan Huberman. Yang terdiri dari reduksi data, penyajian data dan penarikan kesimpulan. Jawaban siswa yang didapatkan dari tes kemudian dianalisis dan digolongkan menjadi berpikir reflektif, cukup reflektif dan kurang reflektif. Kelompok yang mampu berpikir pada ketiga indikator dikatakan siswa berpikir reflektif tinggi. Kelompok yang hanya mampu berpikir pada dua indikator dikatakan siswa reflektif sedang. Sementara kelompok yang yang mampu mengalami berpikir pada satu indikator dikatakan siswa reflektif rendah. Setelah dikelompokkan sesuai dengan tingkatan kemampuan berpikir reflektif matematis yang dimiliki, selanjutnya dianalisis kesulitan yang dialami siswa dalam menyelesaikan soal pada materi operasi hitung pecahan campuran.

Data yang didapatkan harus dapat dipertanggung jawabkan kebenarannya. Untuk mendapatkan keabsahan dari suatu data maka dilakukan pemeriksaan data. Pemerikasaan kebsahan data sangat penting dilakukan. Untuk pelaksanaan dari teknik pemeriksaan ini menggunakan kriteria tertentu. Dalam penelitian ini, pengecekan keabsahan data menggunakan tiangulasi. Triangulasi berguna untuk mencari tahu kebenaran data yang ada dengan cara membandingkan data yang diperoleh dari sumber yang sama, yang didapat pada saat penelitian lapangan dengan teknik pengumpulan data dan juga waktu yang berbeda. Berdasarkan hasil triangulasi, maka hasil akhirnya ada dua kemungkinan yaitu data yang diperoleh konsisten atau tidak konsisten.

\section{Hasil dan Pembahasan}

Hasil yang didapatkan dari tes dan wawancara dibandingkan terlebih dahulu untuk menguji keabsahan data. Setelah dilakukan uji kebasahan data, ada beberapa data yang tidak konsisten sehingga tidak bisa digunakan dan harus dibuang. Proses berpikir reflektif siswa dalam menyelesaikan soal operasi hitung bilangan pecahan campuran ditampilkan pada Tabel 1 berikut.

Tabel 1.

Hasil penelitian

\begin{tabular}{|c|c|c|}
\hline Kode & Hasil Penelitian & Golongan \\
\hline S1 & $\begin{array}{l}\text { Reacting, Comparing dan } \\
\text { Contemplating }\end{array}$ & \multirow{3}{*}{$\begin{array}{l}\text { Kemampuan } \\
\text { berpikir reflektif } \\
\text { matematis tinggi }\end{array}$} \\
\hline S2 & $\begin{array}{l}\text { Reacting, Comparing dan } \\
\text { Contemplating }\end{array}$ & \\
\hline S3 & $\begin{array}{l}\text { Reacting, Comparing dan } \\
\text { Contemplating }\end{array}$ & \\
\hline S4 & Reacting dan Comparing & \multirow{6}{*}{$\begin{array}{l}\text { Kemampuan } \\
\text { berpikir reflektif } \\
\text { matematis sedang }\end{array}$} \\
\hline S5 & Reacting dan Comparing & \\
\hline S6 & Reacting dan Comparing & \\
\hline S10 & Reacting dan Comparing & \\
\hline S12 & Reacting dan Comparing & \\
\hline S13 & Reacting dan Comparing & \\
\hline S15 & Reacting & \multirow{2}{*}{$\begin{array}{l}\text { Kemampuan } \\
\text { berpikir reflektif } \\
\text { matematis rendah }\end{array}$} \\
\hline S16 & Reacting & \\
\hline
\end{tabular}

Dari tabel diatas maka dapat diketahui bahwa ada 3 peserta didik yang tergolong kemampuan berpikir reflektif matematis tinggi, 6 peserta didik tergolong kemampuan berpikir reflektif matematis sedang dan 2 peserta didik tergolong kemampuan berpikir reflektif matematis rendah. Dipilih 1 peserta didik sebagai perwakilan pada setiap golongan, sehingga terdapat 3 peserta didik yang akan dianalisis, yaitu sebagai perwakilan dari siswa dengan kemampuan reflektif matematis tinggi adalah $\mathrm{S} 1$, sementara perwakilan dari siswa dengan kemampuan reflektif matematis sedang adalah S4 dan perwakilan dari siswa dengan kemampuan reflektif matematis rendah adalah S15.

Siswa dengan tingkat kemampuan berpikir reflektif matematis yang tinggi berjumlah 3 siswa dari 12 siswa dengan persentase $25 \%$. Siswa yang dikatakan mempunyai kemampuan berpikir reflektif matematis tinggi mampu mengalami tiga fase berpikir reflektif. Berdasarkan tes dan wawancara yang telah dilakukan, diketahui bahwa siswa dengan kemamuan berpikir reflektif matematis yang tinggi mampu menyelesaikan 4 soal tes yang diberikan dengan benar.

Setiap butir soal tes mengindikasikan tiga fase berpikir reflektif matematis, yaitu reacting, 
comparing dan contemplating. Pada fase reacting siswa diminta untuk melihat dan mengidentifikasi fakta, serta menyebutkan kembali fakta yang ditemukan dengan bahasanya sendiri. Pada fase comparing siswa diminta untuk menjelaskan menghubungkan dan mengaplikasikan konsep dan prinsip yang matematika untuk menemukan solusi. Pada fase contemplating siswa diminta memahami masalah, mengidentifikasi kesalahan dan memperbaiki serta menggunakan konsep untuk memberikan bukti kebenara solusi dan melakukan penarikan kesimpulan.

Sehingga dapat disimpulkan bahwa siswa dengan kemampuan berpikir reflektif matematis yang tinggi tidak mengalami kesulitan dalam menyelesaikan soal. Berdasarkan tes dan wawancara yang telah dilakukan diketahui bahwa siswa dengan kemampuan berpikir reflektif tinggi mampu menyelesaikan soal yang diberikan dengan baik.

Siswa dengan tingkat kemampuan berpikir reflektif sedang berjumlah 6 siswa dari 12 siswa dengan persentase $50 \%$. Siswa yang dikatakan memiliki kemampuan berpikir reflektif matematis sedang hanya mampu mengalami dua fase berpikir reflektif, yaitu reacting dan comparing. Berdasarkan hasil tes dan wawancara, diketahui siswa berkemapuan sedang mampu mengidentifikasi fakta yang tirdapat pada soal, menghubungkan fakta, menemukan solusi dari masalah serta menjelaskan solusi yang ditemukannya serta menghubungkan dengan konsep dan prinsi pada operasi hitung pecahan. Sehingga dari paparan diatas dapat disimpulkan bahwa siswa dengan kemampuan berpikir reflektif sedang mengalami sedikit kesulitan pada fase contemplating, yaitu kesulitan menghubungkan konsep untuk membuktikan kebenaran jawaban dan memberikan penarikan kesimpulan.

Siswa dengan tingkat kemampuan berpikir reflektif matematis rendah berjumlah 2 siswa dari 12 sisiwa degan persentase $17 \%$. Siswa yang dikatakan memiliki kemampuan berpikir reflektif rendah hanya mampu mengalami satu fase saja pada berpikir reflektif, yaitu reacting.
Berdasarkan hasil tes dan wawancara yang telah dilakukan maka diketahui siswa hanya mampu mengidentifikasi fakta dari soal yang diberikan. Sehingga dari pemaparan diatas dapat disimpulkan siswa mengalami kesulitan pada fase comparing dan contemplating, yaitu kesulitan mengaplikasikan konsep dan prinsip untuk menemukan solusi, kesulitan menghubungkankan konsep dan kesulitan memberikan solusi masalah.

Dari hasil dan pembahasana yang telah dipaparkan diatas maka dapat disimpulkan bahwa siswa mengalami kesulitan menerapkan konsep, menghubungkan konsep untuk menyelesaikan masalah, menggunakan prinsip untuk membuktikan kebenaran jawaban. Pernyataan ini didukung oleh hasil penelitian oleh Sholekah et al. (2018) yang menyatakan bahwa kesulitan yang dialami siswa dalam menyelesaikan soal adalah kesulitan mempelajari konsep, menerapkan prinsip dan menyelesaikan masalah verbal. Kesulitan yang dialami oleh siswa lainnya adalah kesulitan dalam memahami masalah pada soal. Siswa sulit untuk menangkap maksud dari soal yang diberikan. Seperti yang dikatakan Fauzi (2018) dalam penelitiannya, siswa banyak mengalami kesulitan pada penafsiran soal yang diakibatkan oleh kemampuan awal siswa masih kurang.

\section{Kesimpulan}

Hasil penelitian yang didapatkan mengenai kesulitan yang dialami siswa dalam menyelesaikan soal operasi hitung bilangan pecahan campuran pada kelas VII SMP Negeri 14 Satu Atap Tanjungpinang sebagai beriku: 1) siswa dengan kemampuan berpikir reflektif matematis tinggi tidak mengalami kesulitan dalam menyelesaikan soal; 2) siswa dengan kemampuan berpikir reflektif sedang mengalami sedikit kesulitan dalam menyelesaikan soal. Kesulitan yang dialami pada fase berpikir reflektif contemplating, dimana siswa kesulitan menghubungkan konsep dan menerapkan prinsip untuk membuktikan kebenaran solusi; 3) siswa dengan kemampuan reflektif matematis rendah mengalami kesulitan dalam menyelesaikan soal. 


\section{JURNAL GANTANG. September 2021; VI(2): 163 - 168 \\ p-ISSN. 2503-0671 \\ e-ISSN. 2548-5547}

Kesulitan yang dialami pada fase comparing dan contemplating, dimana siswa kesulitan mengingat dan menerapkan konsep, siswa kesulitan memahami maksud soal serta siswa kesulitan menyelesaikan masalah yang terjadi dalam kehidupan.

\section{Referensi}

Ariestyan, Y., \& Kurniati, D. (2016). Proses berpikir reflektif siswa dalam menyelesaikan soal matematika materi sistem persamaan linear dua variabel. Kadikma, 7(1), 94-104.

Dian, C. K., Kriswadani, \& Ratu, N. (2018). Analisis kemampuan berpikir reflektif dalam menyelesaikan soal cerita materi persegi bagi siswa kelas VIII SMP kristen 02 salatiga tahun ajaran 2017 / 2018. Paedagoria, 9(1), 1-4.

Dwinata, A., \& Ramadhona, R. (2018). Analisis kesalahan siswa dalam pemecahan problematika kaidah pencacahan titik sampel. Jurnal Gantang, III(2), 117-126.

Emzir. (2012). Metode penelitian kualitatif: analisis data (3rd ed.). Jakarta: PT Raja Grafindo Persada.

Fauzi, L. M. (2018). Identifikasi kesulitan dalam memecahkan masalah matematika. JIPMat: Jurnal Ilmiah Pendidikan Matematika, 3(1), 21-28. https://doi.org/10.26877/ jipmat.v3i1.2286

Hidayah, F. M., Darsono, \& Handayani, A. D. (2018). Analisis kesulitan belajar matematika materi fungsi invers siswa kelas $X$ Apk SMK Pemuda papar tahun ajaran 2017. Simki-Techsain, 02(07), 1-8.

J. Moleong, L. (2014). Metodologi penelitian kualitatif edisi revisi. Bandung: PT Remaja Rosdakarya.

Khasanah, U., \& Sutama. (2015). Kesulitan menyelesaikan soal cerita matematika pada siswa SMP. Prosiding: Seminar Nasional Pendidikan Matematika, 79-89.

Prasetyowati, D., Kartinah, \& Budiman, M. A. (2017). Berpikir reflektif mahasiswa program studi pendidikan matematika universitas PGRI semarang ditinjau dari gaya kognitif field independent $\left(2^{\text {nd }}\right)$. SENATIK: Seminar Nasional Matematika dan Pendidikan Matematika, 184-187.

Putra A. R. C., \& Syarifuddin, A. (2019). Kemampuan koneksi matematis siswa tipe sensing-intuiting dalam menyelesaikan soal olimpiade. Jurnal Gantang, IV(1), 61-70.

Sholekah, L. M., Anggreini, D., \& Waluyo, A (2018). Analisis kesulitan siswa dalam menyelesaikan soal matematika ditinjau dari koneksi matematis materi limit fungsi. WACANA AKADEMIKA: Majalah Ilmiah Kependidikan, 1(2), 151-164. https://doi. org/10.30738/wa.v1i2.1413

Utami, L. (2016). Analisis kesulitan siswa smp kelas vii dalam menyelesaikan soal operasi hitung bilangan dan solusi pemecahannya. Prosiding: Konfensi Nasional Penelitian Matematika dan Pembelajarannya, 246259.

Wahyuni, R. S. (2017). Membandingkan bilangan pecahan menggunakan fraction circle terhadap pemehaman konsep siswa. Jurnal Gantang, II(1), 21-26. 